Vol 3 Nomor 1 - Agustus 2017

ISSN 2460-7878, e-ISSN 2477-5975

\title{
Strategi Penataan Aktifitas Parkir dan Pedagang Kaki Lima pada Koridor Komersial Kota
}

\section{Studi Kasus pada Koridor Jalan Gajah Mada, Sidoarjo}

\author{
Arfiani Syariah ${ }^{1}$ \\ Universitas Islam Negeri Sunan Ampel Surabaya, Indonesia \\ Nisya27@yahoo.com \\ Mega Ayundya Widiastuti \\ Universitas Islam Negeri Sunan Ampel Surabaya, Indonesia \\ m_ayundya@yahoo.com
}

\begin{abstract}
The image characteristics of a city can be seen from it main streets corridor display. One of the aspects that affected the image was related to the parking spaces and street vendors arrangement. Gajah Mada street corridor as one of the main corridor in Sidoarjo City, its main activity was highly influenced by formal and informal commercial activities. Besides having a positive impact, the informal commercial sector also gave a negative impact for the corridor area. The Street vendors have occupied the sidewalk which had lead to pedestrian spatial activities transition up to the roadside. Those activities, along with inadequate parking space, have resulted in traffic congestion along the corridor. The study aimed to formulate the Gajah Mada Street corridor arrangement optimally for all of users convenience. The observations have shown that the traffic smoothness level along the Gajah Mada street varies on each zones. The corridor arrangement strategies was initiated through the parking location, type and time settings as well as the design of each business facilities. This research also has provided policy recommendation that can be taken by the local government related to parking arrangement and street vendors activities along the Gajah Mada street corridor of Sidoarjo.
\end{abstract}

Keywords: commercial corridor, parking arrangement, street vendors, Gajah Mada corridor

Abstrak: Karakter citra dari sebuah kota dapat terlihat dari tampilan koridor jalan utamanya. Salah satu aspek yang mempengaruhi citra adalah terkait penataan parkir dan Pedagang Kaki Lima. Koridor Jalan Gajah Mada sebagai salah satu koridor utama di Kota Sidoarjo, aktifitas utamanya sangat dipengaruhi oleh kegiatan komersial dan perdagangan formal maupun informal. Sektor perdagangan informal selain memberi dampak secara positif, juga memberi dampak negative bagi kawasan tersebut. Pedagang Kaki Lima menempati pedestrian hingga bahu jalan yang mengakibatkan peralihan ruang aktifitas pejalan kaki ke bahu jalan. Aktifitas tersebut, ditambah kurang memadainya lahan parkir, memberikan dampak berupa kemacetan lalu lintas. Tujuan penelitian ini yaitu untuk merumuskan konsep penataan bagi koridor Jalan Gajah Mada yang optimal untuk kenyamanan seluruh penggunanya. Hasil pengamatan menunjukkan tingkat kelancaran lalu lintas di Jalan Gajah Mada berbeda-beda pada setiap zonanya. Strategi penataan koridor dilakukan dengan mengatur lokasi parkir, jenis, waktu dan disain sarana usaha. Penelitian ini juga memberikan beberapa rekomendasi terkait kebijakan yang dapat diambil oleh pemerintah setempat terkait penataan parkir dan aktifitas PKL di Koridor Jalan Gajah Mada Sidoarjo.

Kata Kunci: koridor komersial, penataan parkir, pedagang kaki lima, koridor Gajah Mada

\section{PENDAHULUAN}

Setiap kota pastilah memiliki pola ruang dan identitas yang berbeda. Lintasan cerita suatu kota sering disebut sebagai morfologi kota yang berkembang karena pengaruh dari berbagai aspek (Aldilla, Antariksa, \& Meidian, 2013). Salah satu aspek yang 
mempengaruhi citra dan perkembangan kota yaitu koridor jalan. Koridor jalan juga merupakan ujung tombak identitas pengenal dalam sebuah kawasan dikarenakan karakteristik visualnya yang paling mudah dibaca oleh pengguna jalan. Aspek yang dilihat pengguna tidak hanya dari segi bentuknya saja tetapi dari aktivitas yang dilakukan oleh manusia di dalamnya (Pratama \& Khadiyanto, 2013). Salah satu aktifitas di koridor jalan adalah aktifitas komersial. Koridor komersial sendir didefinisikan sebagai koridor jalan yang pemanfaatan ruang di sepanjang jalannya untuk kegiatan komersial, perkantoran yang kompleks serta pusat pekerjaan di dalam kota (Bishop, 1989).

Perkembangan koridor komersial terjadi pada awal tahun 1980 diawali munculnya kumpulan pertokoan yang kemudian dengan adanya perubahan gaya hidup dan preferensi konsumen pada tahun 1990-an, menyebabkan pergeseran tipologi dari pusat perbelanjaan yang bersifat tertutup beralih ke bentuk open air shopping, yakni kegiatan belanja yang dikombinasikan dengan kegiatan rekreasi ruang terbuka. Selanjutnya perkembangan ini juga menggeser orientasi perilaku berbelanja dimana dari lingkungan belanja yang berorientasi kendaraan sepanjang koridor ke dalam kegiatan belanja yang dilakukan dengan berjalan kaki (Bohl \& Schwanke, 2002).

Koridor Jalan Gajah Mada merupakan salah satu jalur arteri dengan tingkat kepadatan yang cukup tinggi di Kabupaten Sidoarjo. Berdasarkan Rencana Tata Ruang dan Wilayah (RTRW) Kabupaten Sidoarjo tahun 2009-2029, koridor Jalan Gajah Mada memang diperuntukkan bagi perdagangan dan jasa / komersial. Adanya aktivitas perdagangan dan jasa / komersial pada Koridor Jalan Gajah Mada ini turut memberikan dampak positif maupun negatif bagi pengguna dan koridor itu sendiri. Salah satu dampak positifnya adalah meningkatnya perekonomian masyarakat sekitar karena memberikan berbagai peluang usaha, mulai dari pedagang-pedagang kecil sampai komplek pertokoan modern sejenis hypermart ataupun department store. Sedangkan dampak negatif yang timbul diantaranya adalah kemacetan lalu lintas, peralihan fungsi jalur pedestrian yang ditempati pedagang dan parkir liar, serta berkurangnya ruang terbuka. Kondisi parkir dan PKL yang tidak teratur menimbulkan kemacetan pada koridor Jalan Gajah Mada. Selain itu para pengguna kendaraan roda dua banyak yang memarkir kendaraan di jalur pejalan kaki, menyebabkan aktifitas pejalan kaki terganggu dan cenderung enggan untuk berjalan di pedestrian. Penelitian ini mencoba merumuskan strategi penataan koridor Jalan Gajah Mada Sidoarjo sebagai respon terhadap permasalahan yang diakibatkan oleh aktifitas parkir dan pedagang kaki lima.

\section{METODE PENELITIAN}

Penelitian ini merupakan penelitian crosssectional dengan metode deskriptif kualitatif. Data dikumpulkan melalui observasi lapangan dengan terlebih dahulu memecah koridor Jalan Gajah Mada menjadi 3 (tiga) zona. Pengumpulan data dilakukan melalui observasi lapangan. Observasi ditujukan unutk memperoleh gambaran pemetaan terhadap pedestrian, kondisi dan titik kantung parkir serta laju kendaraan di sepanjang koridor jalan Gajah Mada Sidarjo. Hasil data observasi dianalisis dengan pendekatan analisis SWOT untuk menghasilkan rumusan strategi penataan aktifitas parkir dan pedagang kaki lima di sepanjang koridor Jalan Gajah Mada Sidoarjo.

\section{HASIL DAN PEMBAHASAN}

\subsection{Gambaran Umum Koridor Jalan Gajah Mada}

Dalam Peraturan Daerah Nomor 6 tahun 2009 tentang Rencana Tata Ruang Wilayah (RTRW) Kabupaten Sidoarjo tahun 2009-2029 disebutkan bahwa kawasan Sidoarjo merupakan pusat pertumbuhan perdagangan dan jasa. Hal ini tampak jelas dari wajah koridor Jalan Gajah Mada Sidoarjo yang padat oleh pertokoan dan pedagang kaki lima (PKL). Deretan pertokoan dan PKL yang tidak diimbangi dengan penyediaan fasilitas parkir menjadikan sebagian lajur tepi Jalan Gajah Mada Sidoarjo difungsikan sebagai area parkir di banyak titik (on street parking).

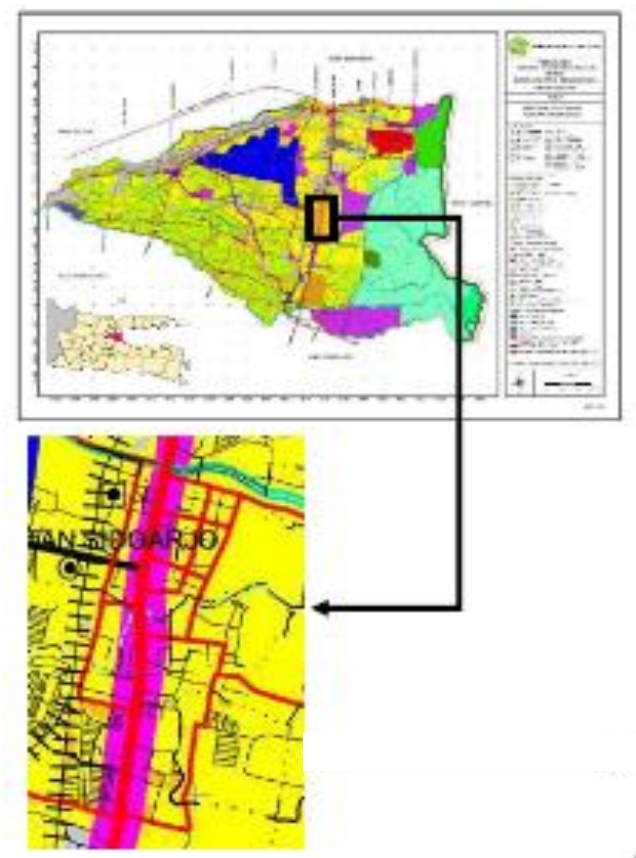

Gambar 1. Lokasi koridor Jalan Gajah Mada terhadap Kabupaten Sidoarjo (sumber: BAPPEDA Kabupaten Sidoarjo, 2009)

Jalan Gajah Mada Sidoarjo yang merupakan salah satu jalur arteri di Kabupaten Sidoarjo, terdiri atas dua atau tiga lajur dengan sistem jalan satu arah, yakni dari arah selatan ke utara. Pemanfaatan lajur jalan untuk area parkir on street semakin mempersempit lebar 
efektif jalan yang menjadi salah satu potensi kemacetan.

\subsection{Pembagian Zona}

Untuk mempermudah aktifitas observasi maka koridor Jalan Gajah Mada dibagi menjadi tiga zona amatan yakni zona A, B, dan C (gambar 2). Setiap zona dibatasi oleh persimpangan besar di Jalan Gajah Mada Sidoarjo. Pemilihan persimpangan jalan sebagai batas zona berdasarkan pertimbangan keberadaan persimpangan pada suatu ruas jalan dapat mempengaruhi kepadatan dan kelajuan lalu lintas kendaraannya yang melintas.

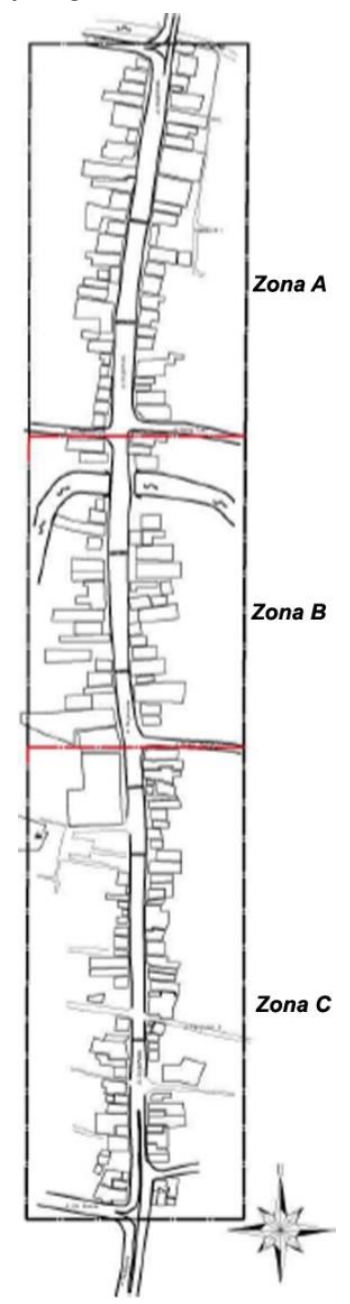

Gambar 2. Pembagian zona koridor Jalan Gajah Mada Sidoarjo (sumber: hasil analisis, 2017)

\subsection{Hasil Pemetaan Koridor}

Untuk memudahkan identifikasi, dilakukan pemetaan secara bertahap pada setiap zona mulai dari pemetaan jenis bangunan, yaitu jenis toko / jasa, pemetaan lokasi PKL beserta jenis dagang dan media dagang, pemetaan jalur pedestrian yang meliputi kondisi, dimensi, jenis material; pemetaan parkir berdasarkan kepemilikan area parkir, sampai dengan pemetaan laju kendaraan berdasarkan tingkat pelayanan lalu lintas yang menggambarkan kecepatan rata-rata kendaraan.

\subsubsection{Jenis Bangunan}

Hasil pemetaan jenis bangunan yang berada di sepanjang koridor Jalan Gajah Mada dapat dilihat pada gambar 3 dan 4 berikut

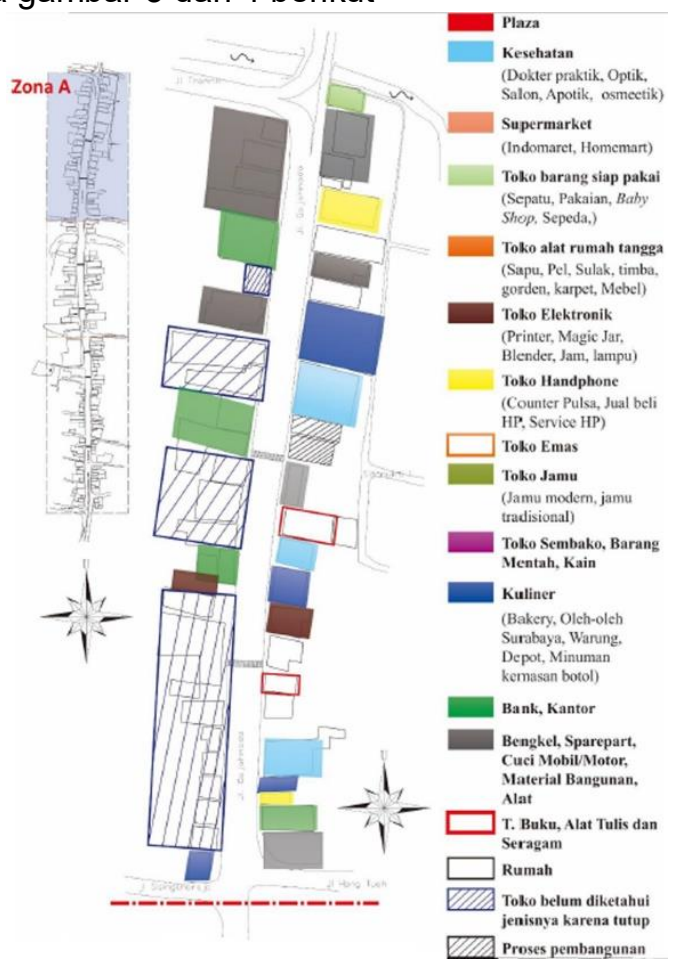

Gambar 3. Pemetaan jenis bangunan zona A koridor jalan Gajah Mada Sidoarjo

(sumber: hasil analisis, 2017)

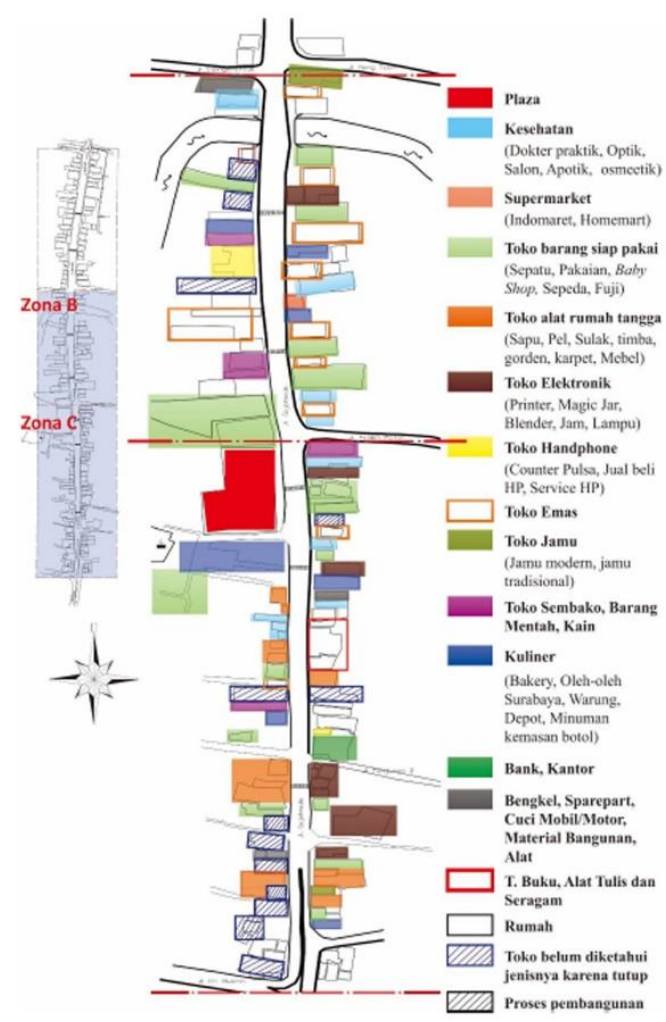

Gambar 3. Pemetaan jenis bangunan zona A \& B koridor jalan Gajah Mada Sidoarjo

(sumber: hasil analisis, 2017) 


\subsubsection{Pedagang Kaki Lima}

Dari hasil pengamatan diperoleh hasil pemetaan titik pedagang kaki lima yang berada di sepanjang koridor Jalan Gajah Mada. (lihat gambar 5 sampai dengan 7).

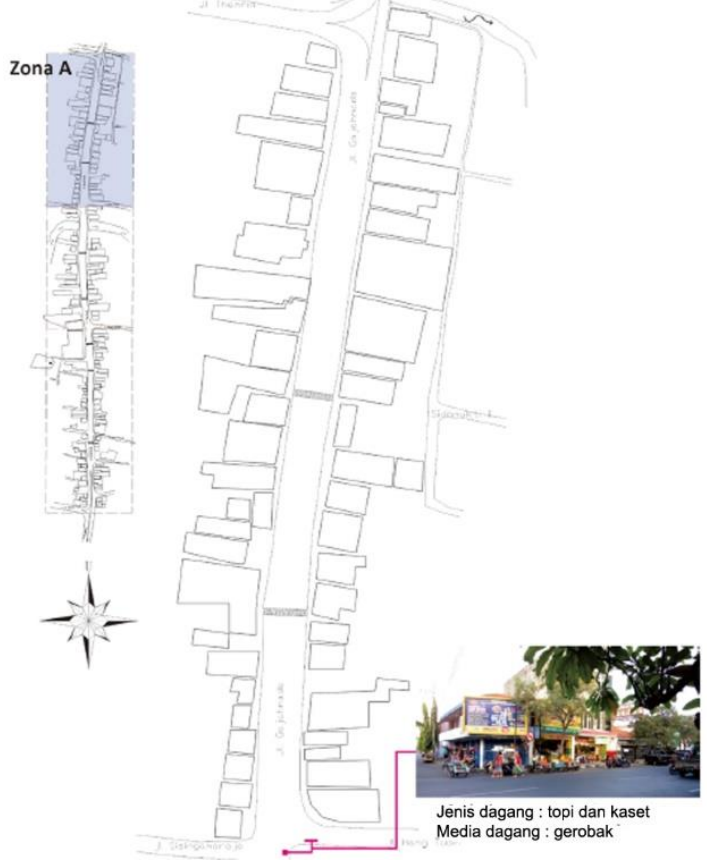

Gambar 5. Pemetaan PKL zona A koridor Jalan Gajah Mada (sumber: hasil observasi, 2017)

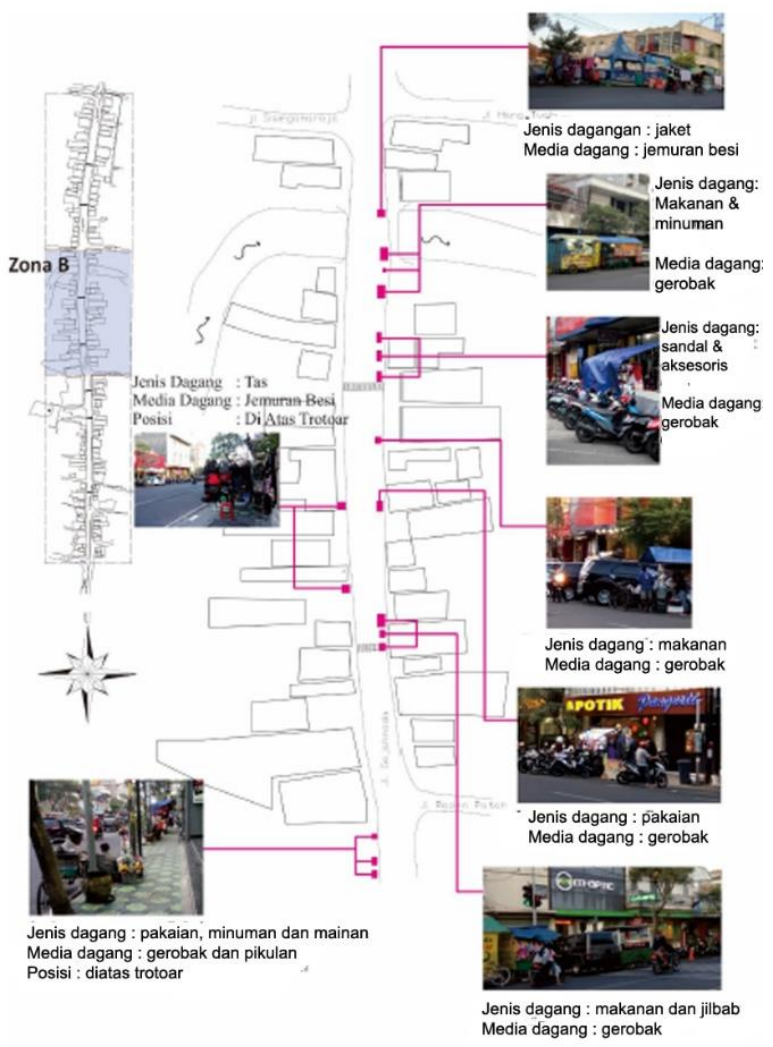

Gambar 6. Pemetaan PKL zona B koridor Jalan Gajah Mada (sumber: hasil observasi, 2017)

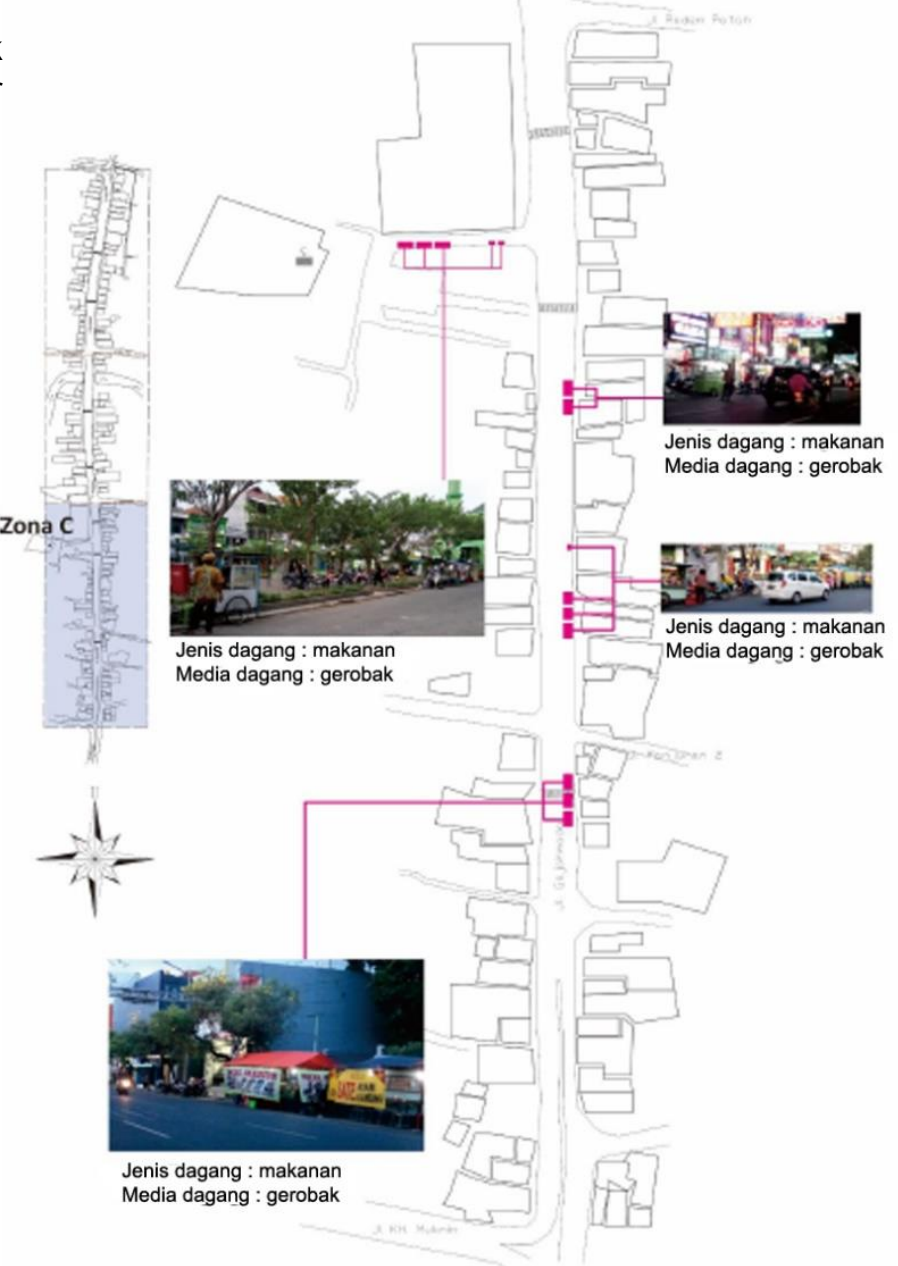

Gambar 7. Pemetaan PKL zona C koridor Jalan Gajah Mada (Sumber: hasil observasi, 2017)

Dari ketiga zona, terlihat bahwa secara visual terlihat zona koridor yang paling banyak diokupasi oleh pedagang kaki lima berturut-turut adalah zona $\mathrm{B}$, zona C dan zona A (lihat tabel 1)

Tabel 1. Rekapitulasi jumlah pedagang kaki lima pada koridor Jalan. Gajah Mada Sidoarjo

\begin{tabular}{cllc}
\hline Zona & Jenis Dagang & Sarana Usaha & Jumlah \\
\hline A & Kaset, Topi & Gerobak & 2 \\
B & Jaket, makanan & Gerobak, & 17 \\
& dan minuman, pikulan, & \\
& $\begin{array}{l}\text { Sandal, aksesoris, } \\
\text { tas, pakaian, }\end{array}$ & \\
& jilbab, mainan & & \\
C & Makanan & Gerobak & 14 \\
\hline
\end{tabular}

sumber: hasil analisis, 2017

\subsubsection{Kondisi pedestrian}

Pemetaan kondisi pedestrian meliputi amatan terhadap kondisi fisik pedestrian, dimensi serta material dari pedestian itu sendiri. Hasil pemetaan kondisi pedestrian pada masing-masing zona dapat dilihat pada gambar 8,9 dan 10 berikut 


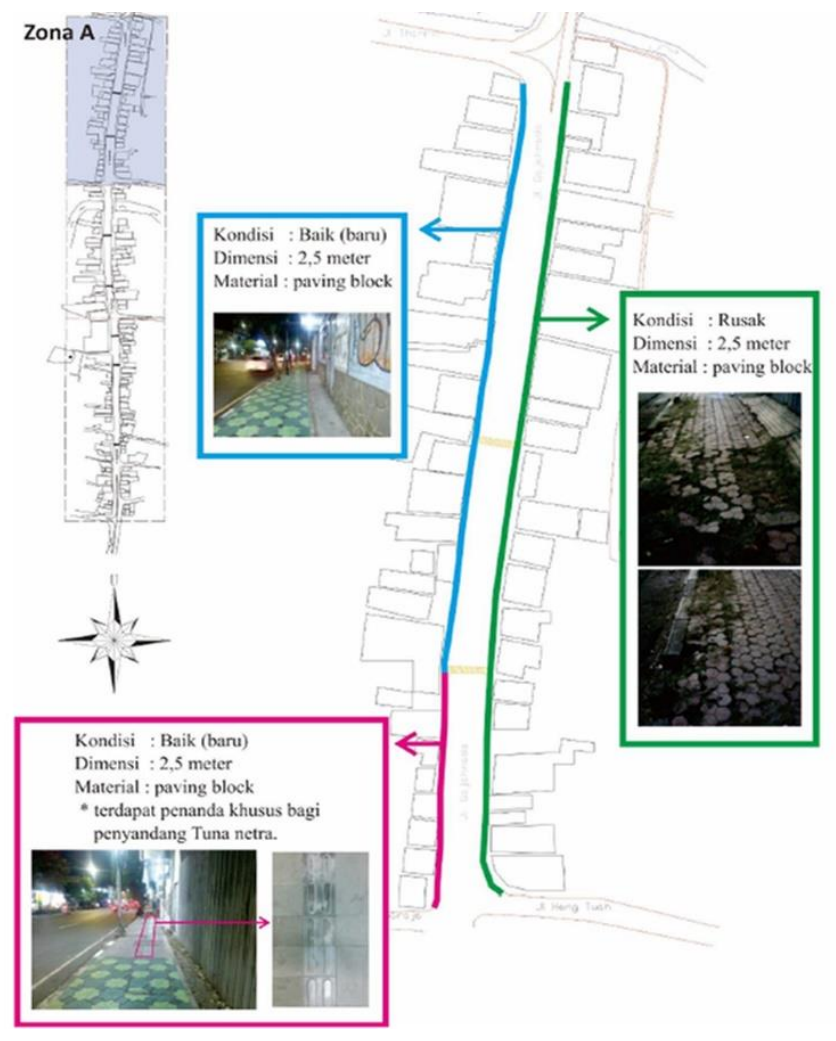

Gambar 8. Pemetaan pedestrian zona A koridor Jalan Gajah Mada (sumber: hasil observasi, 2017)

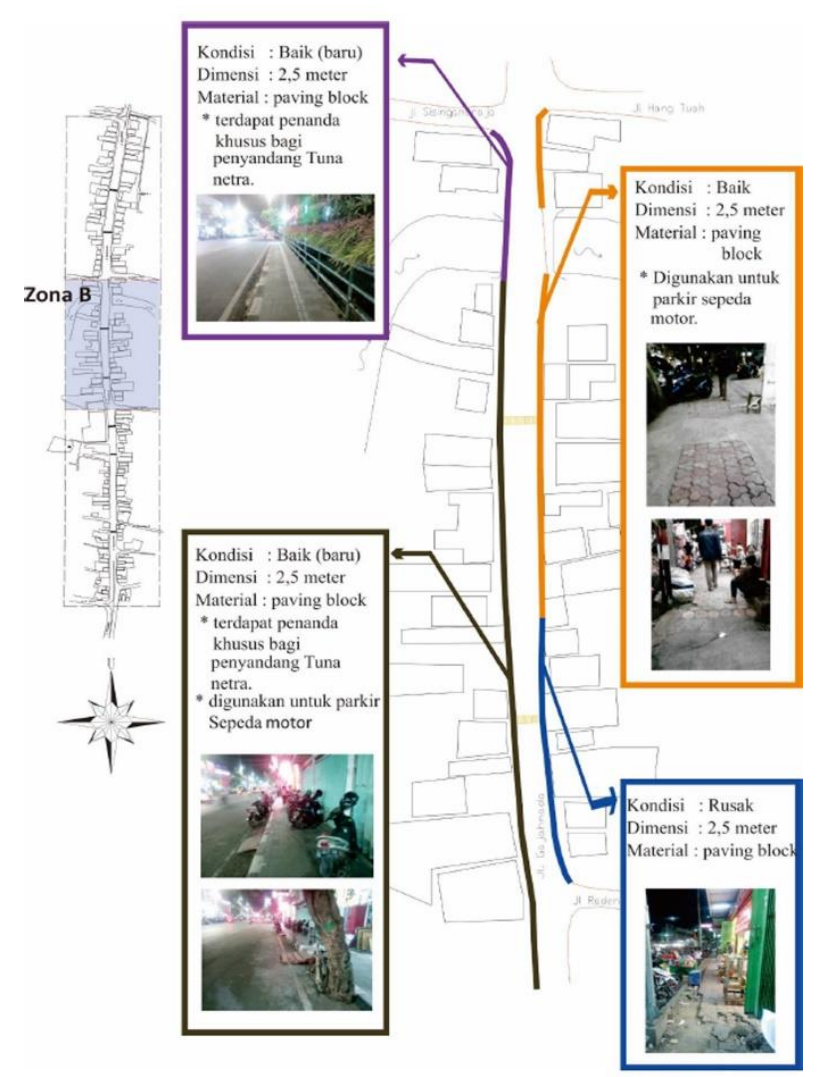

Gambar 9. Pemetaan pedestrian zona B koridor Jalan Gajah Mada (sumber: hasil observasi, 2017)

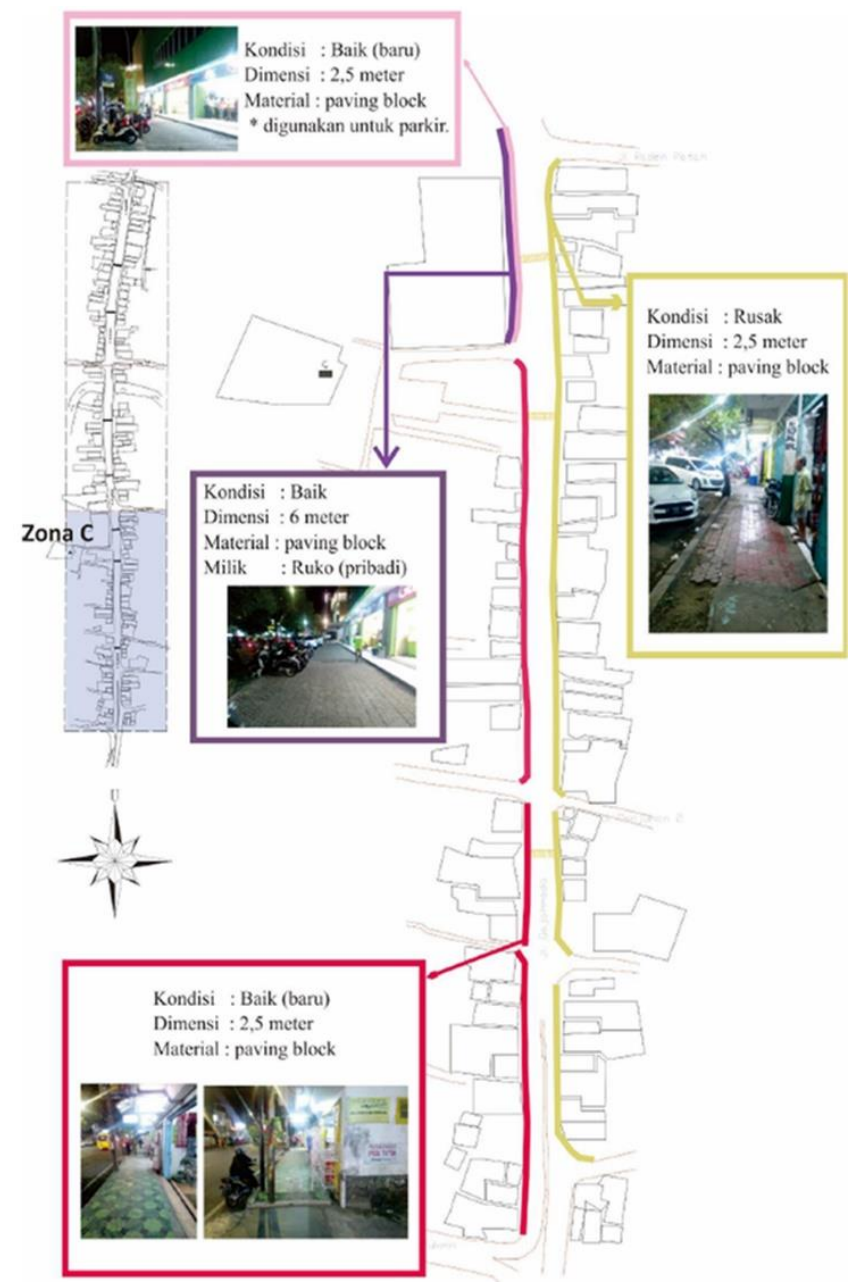

Gambar 10. Pemetaan pedestrian zona C koridor Jalan Gajah Mada (sumber: hasil observasi, 2017)

Dari hasil observasi diketahui bahwa kondisi jalur pedestrian pada koridor Jalan Gajah Mada dalam kondisi bervariasi, dimana pada sisi timur pada zona A, sebagian kecil pada sisi timur zona B serta pada sisi timur zona $C$ berada dalam kondisi yang rusak. Untuk material jalur pedestrian pada koridor Jalan Gajah Mada sendiri seluruhnya sudah terbuat dari paving block, dengan lebar jalur pedestrian umumnya berukuran 2.5 meter, kecuali pada sebagian kecil pada zona C yang lebar pedestriannya mencapai 6 meter. Selain itu pada jalur pedestrian di sisi barat koridor jalan Gajah Mada telah dilengkapi dengan fasilitas penanda khusus yang ditujukan bagi para kelompok difabel (tuna netra).

\subsubsection{Kondisi Parkir}

Pemetaan kondisi parkir meliputi amatan terhadap situasi dan titik kantong parkir disepanjang koridor Jalan Gajah Mada, termasuk jenis kepemilikan / pengelolaan titik parkir (milik pemerintah kabupaten atau tidak). Hasil pemetaan kondisi situasi titik kantong parkir pada koridor Jalan Gajah Mada pada masingmasing zona dapat dilihat pada gambar 11, 12 dan 13 berikut 


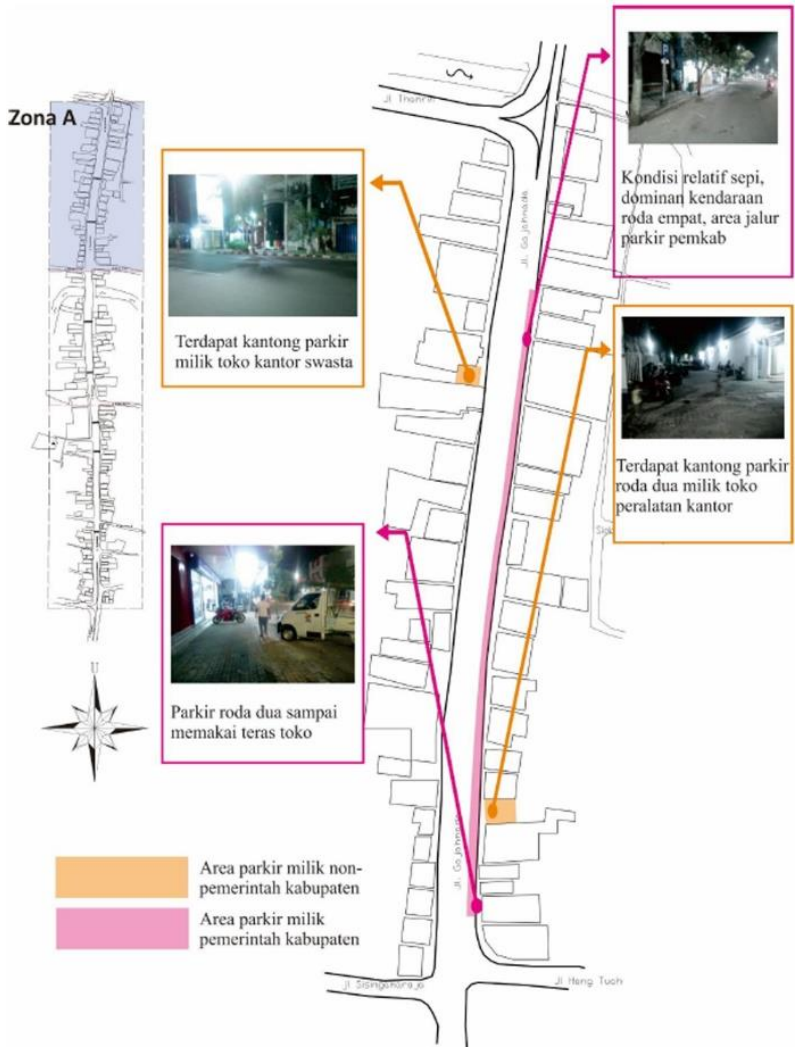

Gambar 11. Pemetaan titik parkir pada zona A koridor Jalan Gajah Mada (sumber: hasil observasi, 2017)

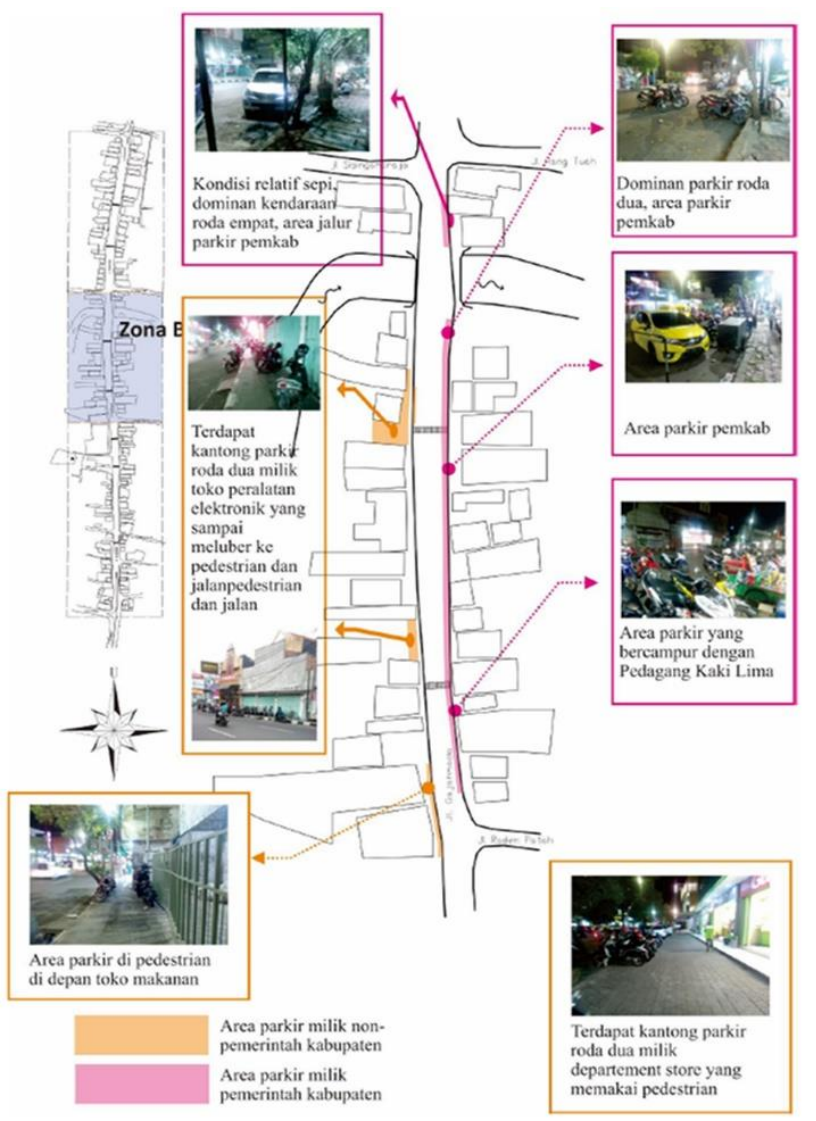

Gambar 12. Pemetaan titik parkir pada zona B koridor Jalan Gajah Mada (sumber: hasil observasi, 2017)

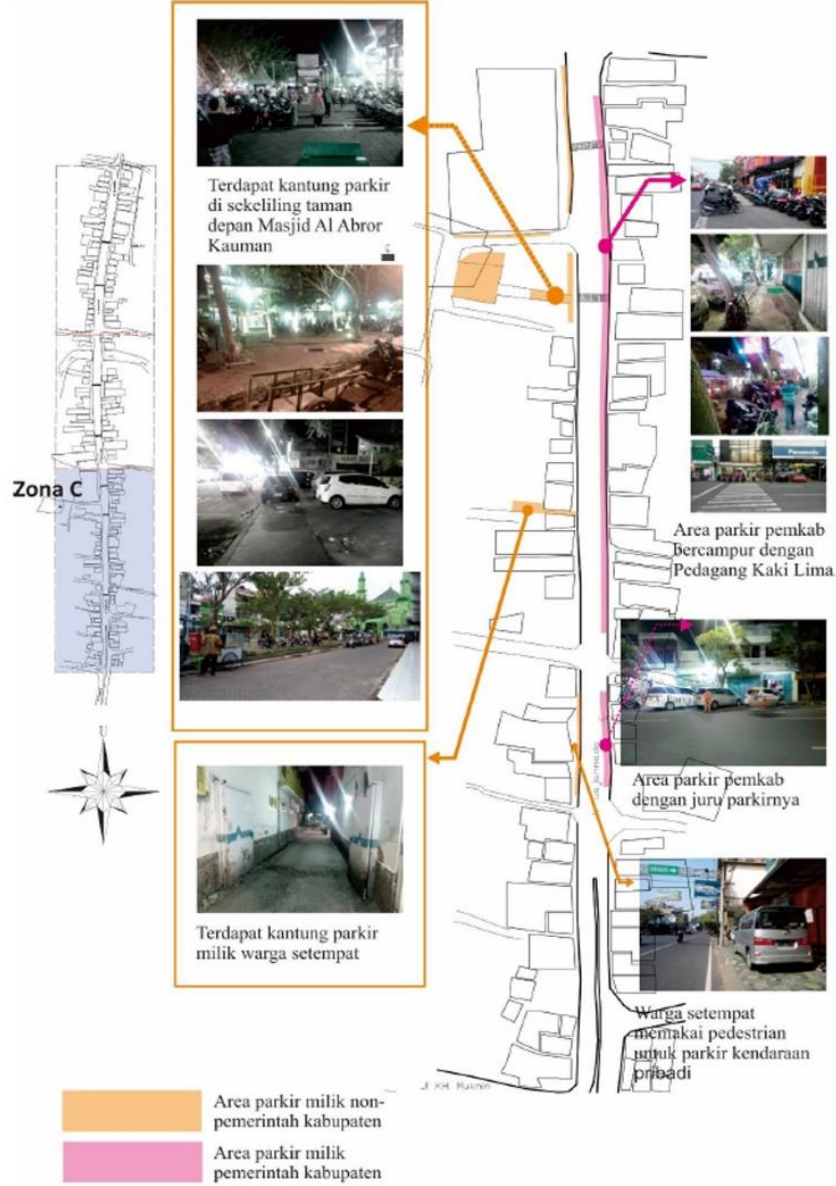

Gambar 13. Pemetaan titik parkir pada zona C koridor Jalan Gajah Mada (sumber: hasil observasi, 2017)

Dari hasil amatan dapat diketahui bahwa terdapat setidaknya 16 titik kantong parkir di sepanjang koridor Jalan Gajah Mada, dengan rincian jenis pengelolanya seperti terlihat pada tabel 2 berikut.

Tabel 2. Jumlah titik parkir di sepanjang koridor Jalan Gajah Mada berdasarkan pengelolanya

\begin{tabular}{ccc}
\hline \multirow{2}{*}{ Zona } & \multicolumn{2}{c}{ Jumlah titik parkir } \\
\cline { 2 - 3 } & pemerintah & non-pemerintah \\
\hline A & 2 & 2 \\
B & 4 & 3 \\
C & 2 & 3 \\
\hline Total & 8 & 8 \\
\hline
\end{tabular}

sumber: hasil observasi, 2017

\subsubsection{Laju Kendaraan}

Pemetaan laju kendaraan ditujukan untuk mengetahui kecenderungan terjadinya kemacetan lalu lintas kendaraan bermotor di sepanjang koridor Jalan Gajah Mada Sidoarjo. Untuk melakukan katagorisasi pada koridor Jalan Gajah Mada ini digunakan 6 tingkatan pelayanan jalan perkotaan yakni tingkat pelayanan $A$, B, C, D, E dan F (lihat detail pada tabel 3). 
Tabel 3. Klasifikasi tingkat pelayanan jalan raya

\begin{tabular}{|c|c|}
\hline Tingkat & Deskripsi \\
\hline A & $\begin{array}{l}\text { Keadaan arus lalu lintas yang bebas } \\
\text { (free flow), volume rendah, dan } \\
\text { kecepatan tinggi, pengemudi dapat } \\
\text { memilih kecepatan yang dikehendaki } \\
\text { sesuai keadaan fisik kendaraan dan } \\
\text { pembatasan kecepatan serta tidak } \\
\text { menimbulkan tundaan. Kecepatan } \\
\text { perjalanan rata-rata } 90 \% \text { dari kecepatan } \\
\text { arus bebas. }\end{array}$ \\
\hline$B$ & $\begin{array}{l}\text { Keadaan arus lalu lintas stabil, } \\
\text { kecepatan perjalanan mulai dipengaruhi } \\
\text { oleh keadaan lalu lintas, pengemudi } \\
\text { masih mendapat kebebasan yang cukup } \\
\text { dalam memilih kecepatan. Kecepatan } \\
\text { perjalanan rata-rata sebesar } 70 \% \text { dari } \\
\text { kecepatan arus bebas. }\end{array}$ \\
\hline C & $\begin{array}{l}\text { Keadaan arus lalu lintas stabil, } \\
\text { kecepatan dan gerakan lebih ditentukan } \\
\text { oleh volume yang tinggi sehingga } \\
\text { pemilihan kecepatan sudah terbatas } \\
\text { dalam batas-batas kecepatan jalan yang } \\
\text { masih cukup memuaskan. Besaran ini } \\
\text { digunakan untuk ketentuan perencanaan } \\
\text { jalan-jalan dalam kota. Kecepatan } \\
\text { perjalanan rata-rata } 50 \% \text { dari kecepatan } \\
\text { arus bebas. }\end{array}$ \\
\hline $\mathrm{D}$ & $\begin{array}{l}\text { Menunjukkan keadaan yang mendekati } \\
\text { tidak stabil, dimana kecepatan yang } \\
\text { dikehendaki secara terbatas masih dapat } \\
\text { dipertahankan meskipun sangat } \\
\text { dipengaruhi oleh perubahan-perubahan } \\
\text { dalam keadaan perjalanan yang dapat } \\
\text { menurunkan kecepatan yang cukup } \\
\text { besar, sehingga menyebabkan } \\
\text { kebebasan bergerak dan kenyamanan } \\
\text { rendah. Kecepatan perjalanan rata-rata } \\
\text { sebesar } 40 \% \text { dari kecepatan arus bebas. }\end{array}$ \\
\hline$E$ & $\begin{array}{l}\text { Merupakan arus lalu lintas yang tidak } \\
\text { stabil dan tidak dapat ditentukan hanya } \\
\text { dari kecepatan perjalanan saja, sering } \\
\text { terjadi kemacetan (berhenti) untuk } \\
\text { beberapa saat. Volume hampir atau } \\
\text { sama dengan kapasitas jalan. } \\
\text { Kecepatan perjalanan rata-rata sebesar } \\
33 \% \text { dari kecepatan arus bebas. }\end{array}$ \\
\hline$F$ & $\begin{array}{l}\text { Menunjukkan arus jalan perkotaan } \\
\text { dengan kecepatan sangat rendah, } \\
\text { volume sangat tinggi, terjadi antrian yang } \\
\text { panjang dan terjadi tundaan. Kecepatan } \\
\text { rata-rata sebesar } \pm 30 \% \text { dari kecepatan } \\
\text { arus bebas. }\end{array}$ \\
\hline
\end{tabular}

Sumber: Transportation Research Board dalam Bakhtiar \& Aji, 2017
Adapun hasil pemetaan laju kendaraan pada koridor Jalan Gajah Mada pada masing-masing zona dapat dilihat pada gambar 14 berikut.

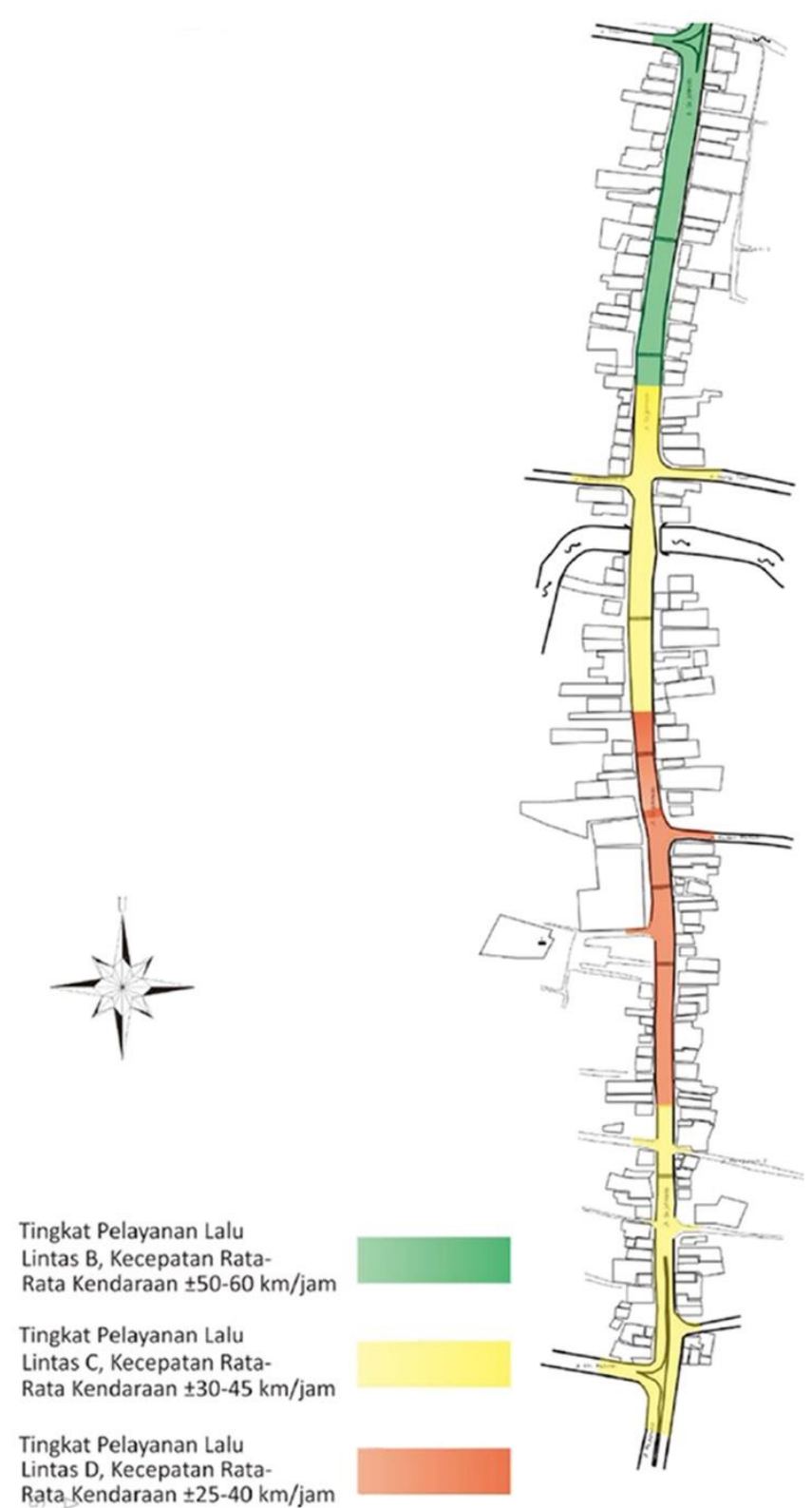

Gambar 14. Pemetaan laju kendaraan pada koridor Jalan Gajah Mada (sumber: hasil observasi, 2017)

\subsection{Analisis Overlay Koridor}

Tingkat kepadatan aktifitas komersial pada zona A tergolong rendah. Hal ini disebabkan oleh beberapa jenis bangunan di zona ini seperti bengkel, kantor / bank, dan toko yang sering tutup (ketika dilakukan survei baik pada pagi, siang, maupun malam hari). Rendahnya aktifitas komersial berdampak pada kondisi lalu lintas jalan yang menjadikannya lebih lancar. Pada gambar 15 terlihat hasil overlay peta pemetaan jenis toko, PKL dan laju kendaraan pada zona A koridor Jalan Gajah Mada Sidoarjo. 


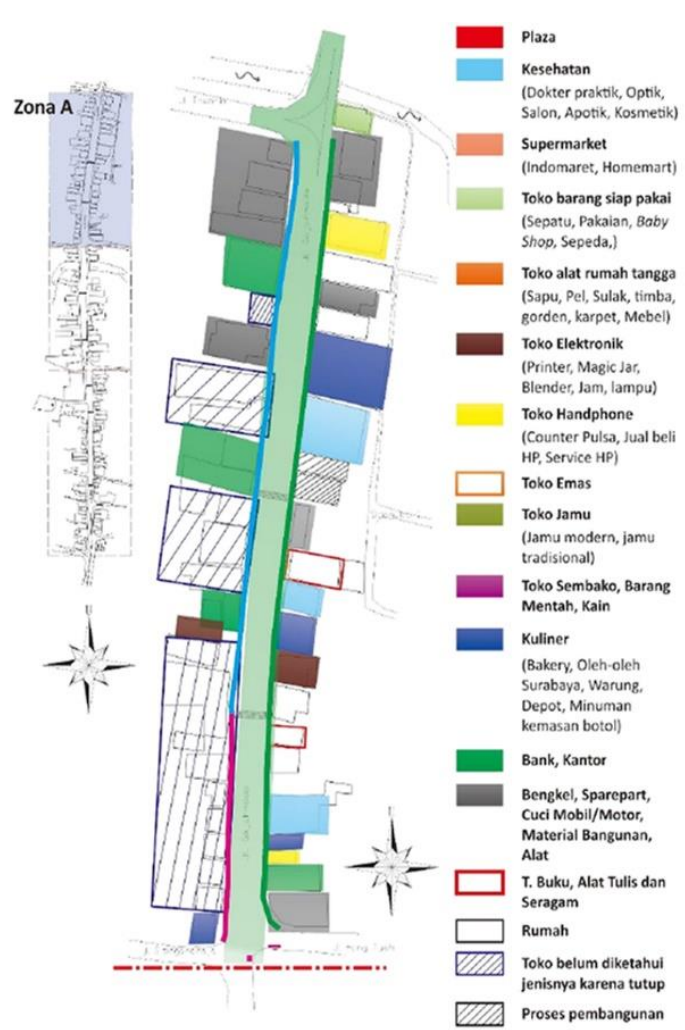

Gambar 15. Hasil overlay peta pada zona A koridor Jalan Gajah Mada (Sumber: Analisis, 2017)

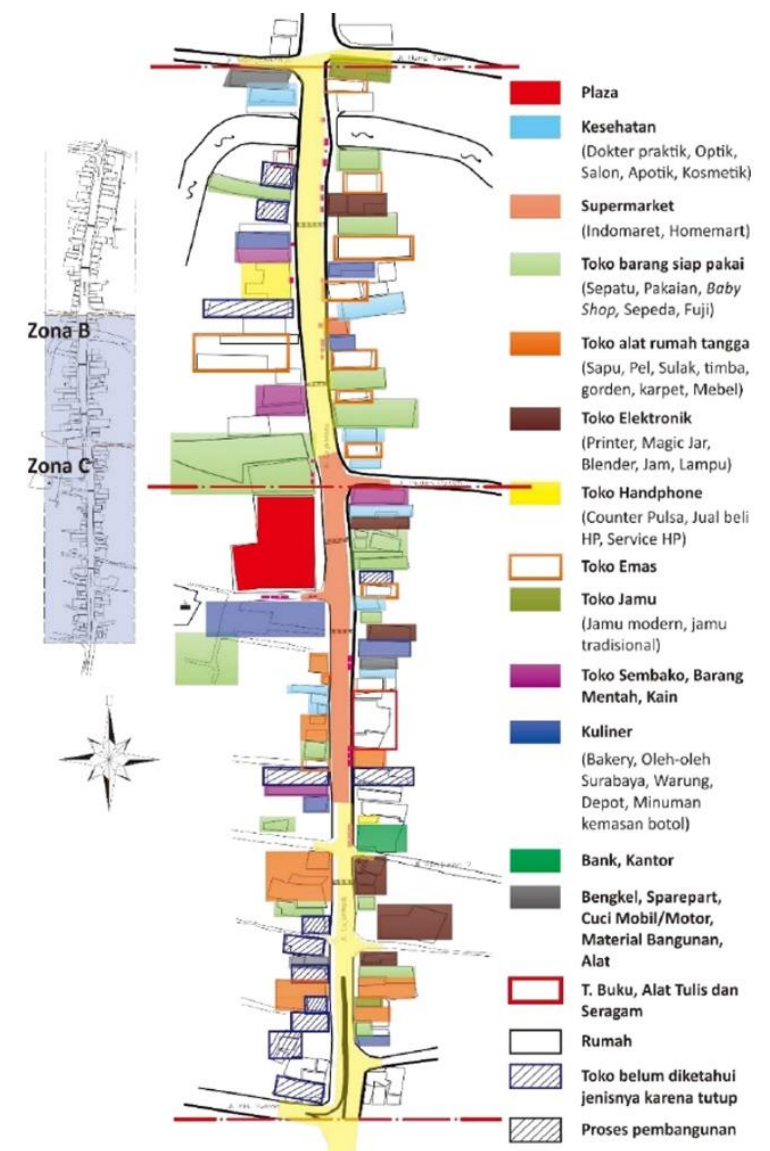

Gambar 16. Hasil overlay peta pada zona B dan zona C pada koridor Jalan Gajah Mada (Sumber: Analisis, 2017)
Tingkat kepadatan komersial pada zona B tergolong tinggi. Hal ini disebabkan oleh beragamnya jenis toko dan banyaknya jumlah PKL sehingga pengunjung di zona ini lebih banyak. Kondisi parkir dan lalu lintas jalan ikut padat seiring dengan tinginya jumlah pengunjung. Disamping itu, zona B mempunyai lebar jalan yang lebih kecil dari zona A sehingga menambah potensi kemacetan jalan. Sedangkan zona $\mathrm{C}$ memiliki tingkat kepadatan aktifitas komersial yang sedang. Hal ini dikarenakan PKL yang ada di area ini juga tidak terlalu banyak. Hasil overlay peta jenis toko, PKL dan laju kendaraan pada zona A dan zona B pada koridor Jalan Gajah Mada Sidoarjo terlihat pada gambar 16.

\subsection{Analisis SWOT}

Dari hasil observasi dan pemetaan pada koridor Jalan Gajah Mada Sidoarjo, maka dilakukan identifikasi terhadap kekuatan (strength), kelemahan (weakness), peluang (opportunity) dan ancaman (threat) terkait upaya penataan koridor Jalan Gajah Mada Sidorajo. Adapun kekuatan yang dimiliki dari kondisi saat ini diantaranya:

1. Keberadaan PKL meningkatkan ekonomi masyarakat dari sektor informal

2. Keberadaan PKL menjadi identitas yang menghidupkan kawasan

3. Kestrategisan Jalan Gajah Mada yang merupakan salah satu koridor utama Kota Sidoarjo

4. Jenis dagangan yang beragam, menjadi alternatif tujuan masyarakat Kota Sidoarjo untuk mencari kebutuhan sehari-hari

5. Harga jual produk dagangan baik kuliner maupun kebutuhan sehari-hari relatif murah dan dapat dijangkau pembeli kelas menengah ke bawah

6. Berada di koridor komersial kota dengan sarana penunjang berupa tempat peribadatan, lokasi tujuan wisata dan pertokoan

7. Memiliki beberapa bangunan kosong di Koridor Gajahmada

8. Dimensi jalan di beberapa segmen memiliki dimensi yang lebih lebar dari sekitarnya.

Sedangkan kelemahannya meliputi:

1. Aktifitas PKL tidak didukung oleh ketersediaan lahan parkir yang mecukupi,

2. Tidak didukung oleh penyediaan street furniture yang memadai, sehingga mengurangi kenyamanan dan estetika ruang kota,

3. Jenis dagangan berupa makanan tidak di dukung dengan aturan pola kegiatan dan penyediaan prasarana pendukung, sehingga aktifitas memasak dan mencuci bekas alat makan yang dilakukan di tempat merusak estetika koridor,

4. Pihak pemerintah belum memberikan solusi dan inovasi terkait dengan permasalahan yang ada,

5. Aktifitas $P K L$ yang berada di pedestrian dan bahu jalan mengganggu aktifitas pejalan kaki, parkir dan pengguna jalan. 
Untuk peluang yang mendukung penataan koridor Jalan Gajah Mada diantaranya adalah:

1. Adanya kebijakan pemerintah daerah tentang Penataan dan Pemberdayaan PKL yang tertuang dalam Peraturan Daerah Kabupaten Sidoarjo Nomor 3 Tahun 2016,

2. Kemampuan daya beli masyarakat yang meningkat, serta

3. Pola pikir masyarakat yang semakin praktis

Sedangkan ancaman terhadap upaya penataan koridor Jalan Gajah Mada diantaranya meliputi:

1. Pola pikir pedagang kaki lima tentang penataan masih identik dengan relokasi yang akan merugikan mereka

2. Pola pikir masyarakat pembeli bahwa dengan tampilan PKL yang lebih baik akan menaikkan harga jual produk dibandingkan sebelumnya

3. Kebiasaan masyarakat pembeli yang malas untuk berjalan jauh dari titik parkir untuk membeli barang kebutuhan mereka

4. Beberapa pedagang dengan jenis dagangan yang sama berada di satu titik area

5. PKL berada di koridor komersial Kabupaten Sidoarjo yang penggunaan lahan di dominasi oleh perdagangan jasa dapat menimbulkan permasalahan sosial.

\subsection{Strategi}

Berdasarkan hasil analisis SWOT maka dirumuskan beberapa strategi seperti terlihat pada tabel 4 berikut.

Tabel 4. Matrik strategi penataan koridor Jalan Gajah Mada Sidoarjo

\begin{tabular}{|c|c|c|}
\hline & Opportunity & Threat \\
\hline 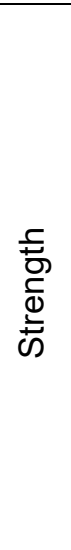 & $\begin{array}{l}\text { a. Melakukan penataan PKL dengan prinsip } \\
\text { kemanusiaan, keadilan, kemitraan, kepastian } \\
\text { hukum, kejujuran usaha dan persaingan sehat } \\
\text { b. Menempatkan ruang PKL sebagai salah satu } \\
\text { penunjang destinasi wisata } \\
\text { c. Menerapkan konsep simbiosis mutualisme antara } \\
\text { kegiatan pertokoan dengan aktifitas PKL } \\
\text { d. Memanfaatan bangunan-bangunan kosong yang } \\
\text { dapat dialihfungsikan sebagai ruang usaha parkir } \\
\text { dan penempatan PKL } \\
\text { e. Menerapkan konsep pengaturan zona parkir pada } \\
\text { jam dan zona tertentu sesuai dengan karakteristik } \\
\text { aktifitas koridor }\end{array}$ & $\begin{array}{ll}\text { a. } & \text { Rebranding penataan PKL dengan membuat } \\
\text { aturan terkait harga jual dagangan yang tetap } \\
\text { b. Melengkapi jalan penghubung antara tempat } \\
\text { parkir dan ruang PKL dengan street furniture } \\
\text { yang nyaman dan estetis } \\
\text { c. Penataan jenis dan lokasi dagang PKL dengan } \\
\text { tetap mempertahankan prinsip partisipatif dan } \\
\text { pemberdayaan } \\
\text { d. Penempatan titik PKL tidak menghalangi arah } \\
\text { pandang calon konsumen ke etalase pertokoan } \\
\text { e. Lokasi penempatan titik PKL harus didukung } \\
\text { dengan rencana tata ruang dengan melakukan } \\
\text { studi kelayakan terlebih dahulu }\end{array}$ \\
\hline & $\begin{array}{l}\text { a. Melakukan identifikasi dan penempatan titik } \\
\text { parkir pada berbagai ruang yang memungkinkan } \\
\text { untuk dimanfaatkan. } \\
\text { b. Melakukan rekayasa lalu lintas pada jam dan } \\
\text { hari tertentu } \\
\text { c. Melengkapi koridor jalan dengan street furniture } \\
\text { yang nyaman, estetis dan efektif bagi pengguna } \\
\text { d. Melakukan branding kawasan dengan } \\
\text { mendesain lapak PKL sesuai dengan tema } \\
\text { wisata kawasan } \\
\text { e. Menempatkan beberapa PKL dengan jenis } \\
\text { dagangan makanan dan minuman ringan tetap } \\
\text { di dalam ruang pedestrian untuk fasilitas } \\
\text { penunjang bagi pejalan kaki } \\
\text { fesain lapak PKL dilengkapi dengan fasilitas } \\
\text { tempat cuci yang langsung terhubung dengan } \\
\text { saluran drainase kota } \\
\text { gelakukan identifikasi dan relokasi PKL ke } \\
\text { ruang potensial lain di sepanjang koridor serta } \\
\text { melengkapi dengan sarpras pendukung yang } \\
\text { memadai supaya menarik pengunjung }\end{array}$ & $\begin{array}{l}\text { a. Menempatkan PKL dengan pola layanan hanya } \\
\text { take away di sepanjang pedestrian } \\
\text { b. Memperbaiki sistem parkir } \\
\text { c. Melakukan penataan PKL dengan tetap } \\
\text { memperhatikan karakteristik perilaku } \\
\text { konsumen } \\
\text { d. Melengkapi lokasi relokasi PKL dengan fasilitas } \\
\text { penunjang untuk aktifitas tambahan dan view } \\
\text { yang menarik pengunjung. } \\
\text { e. Memanfaatkan media sosial untuk kegiatan } \\
\text { promosi }\end{array}$ \\
\hline
\end{tabular}


Strategi Penataan Aktivitas Parkir dan Pedagang Kaki Lima...

\section{KESIMPULAN}

Berdasarkan hasil identifikasi kondisi eksisting dan analisis, dapat ditarik beberapa kesimpulan terkait penataan aktifitas parkir dan pedagang kaki lima di koridor Jalan Gajah Mada Sidoarjo, yaitu:

1. Tingkat kelancaran lalu lintas pada Jalan Gajah Mada berbeda-beda pada tiap zona yang dipengaruhi oleh jenis toko jumlah dan persebaran PKL serta perletakan parkir sepanjang koridor Jalan Gajah Mada,

2. Konsep penataan PKL dapat dilakukan dengan mengatur lokasi, jenis, waktu dan desain tempat penjualan

3. Konsep penataan parkir dapat dilakukan dengan mengatur waktu dan titik lokasi perparkiran

4. Perlu adanya jalur penghubung antar ruang parkir, $\mathrm{PKL}$ dan pertokoan yang nyaman dan aman untuk keberlanjutan kegiatan komersial koridor.

Dari kesimpulan tersebut beberapa rekomendasi dapat disarankan diantaranya adalah:

1. Perda penataan dan pemberdayaan PKL hendaknya di dukung dengan studi kelayakan dan perda rencana tata ruang yang mengatur lokasi penempatan titik PKL termasuk di koridor Gajah Mada

2. Penataan aktivitas parkir dan PKL hendaknya didukung dengan dokumen Rencana Tata Bangunan dan Lingkungan koridor.

3. Penataan dan Pemberdayaan disertai dengan pendampingan

4. Melakukan FGD dengan pemilik bangunan yang tidak digunakan untuk usaha di sepanjang koridor agar melakukan perubahan pemanfaatan sebagai area parkir dan ruang usaha PKL yang dapat memberikan pemasukan bagi mereka

5. Penataan koridor harus melibatkan seluruh stakeholder yaitu pemilik toko, PKL dan masyarakat sehingga koridor Gajah Mada menjadi aman dan nyaman

\section{DAFTAR PUSTAKA}

Aldilla, R., Antariksa, \& Meidian, C. (2013). Identifikasi Bangunan Kuno di Koridor Jalan Gajah Mada Sidoarjo. ARSKON Jurnal Arstitektur Dan Konstruksi, 2(1), 79-93.

Bakhtiar, M. A., \& Aji, S. (2017). Penentuan Lokasi Rawan Kecelakaan Menggunakan Aplikasi Sistem Informasi Gegrafis Pada Ruas Jalan Mayjend Panjaitan Kota Madiun. In PROSIDING SEMINAR NASIONAL HASIL PENELITIAN UNIVERSITAS MERDEKA MADIUN 2017 (pp. 11-22). Madiun: Lembaga Penelitian dan Pengabdian kepada Masyarakat Universitas Merdeka Madiun.

BAPPEDA Kabupaten Sidoarjo. (2009). RENCANA TATA RUANG WILAYAH KABUPATEN SIDOARJO TAHUN 2009 - 2029. Retrieved 22 December 2017, from http://bappeda.sidoarjokab.go.id/haldownload2.html

Bishop, K. R. (1989). Designing urban corridors.

Bohl, C. C., \& Schwanke, D. (2002). Place making: developing town centers, main streets, and urban villages. Urban Land Inst.

Pratama, A., \& Khadiyanto, P. (2013). Identifikasi Perilaku Masyarakat dalam Perparkiran OnStreet di Koridor Jalan Gajah Mada Semarang Sebagai Kawasan Komersial. Ruang, 1(1), 4150 . 